\title{
Effects of School-related Factors and Early Learning Experiences on Mathematics Achievement "A Multilevel Analysis to Analyse the TIMSS Data"*
}

\author{
Sıdıka Akyüz Aru ${ }^{1}$, Mustafa Kale ${ }^{2}$ \\ ${ }^{1}$ Ministry of Education, Ankara, Turkey \\ ${ }^{2}$ Gazi Faculty of Education, Gazi University, Ankara, Turkey \\ Correspondence: Sıdıka Akyüz Aru, Ministry of Education, Ankara, Turkey.
}

Received: January 6, 2019

doi:10.11114/jets.v7i4.3949

Accepted: March 24, 2019

Online Published: March 26, 2019

URL: https://doi.org/10.11114/jets.v7i4.3949

\begin{abstract}
The overall aim of this study is to investigate the effect of school-related factors and early learning experiences on mathematics achievement. In this causal-comparative research, HLM analysis was performed on the data of 6378 students, their parents, and 241 school principals and primary school teachers. As a result of the HLM analysis, at the student level, learning resources at home, parent-child communication on homework/assignments, parent-child activities in early learning years, and the skills acquired during these years were found to have statistically significant effects on the mathematics academic achievement scores of primary school students. At the school level, on the other hand, the socioeconomic structure of the school, the importance that the school attaches to mathematics academic achievement and teachers' perceptions about it, teachers' experiences, and a safe and disciplined school environment have significant effects. These results indicate the importance of early learning experiences especially in the development of the academic performance of primary school students.
\end{abstract}

Keywords: early learning experiences, school characteristics, TIMSS 2015, mathematics achievement, HLM analysis

\section{Introduction}

Considering the education system's objectives of raising effective individuals, the quality of educational activities comes to the forefront to raise individuals with prediction skills, curiosity, and an improved ability to reason, analyse, and to solve real-life problems. Increasing the quality of education improves students' knowledge and skills in different areas and enables them to perform better.

The approach to be adopted to carry out the monitoring and evaluation activities in line with this in a healthy manner is important. Reddy (2005) argues that the most realistic approach to such activities is an international comparison. International comparisons help compare different education systems and provide countries with the opportunity to make necessary changes in light of the scientific data.

In this respect, one of the international applications that Turkey has participated is the 'Trends in Mathematics and Science Study- TIMSS', applied to students at grades 4 and 8 in four-year periods by IEA. It aims to evaluate students' mathematics and science knowledge and skills (IEA, 2017). For this purpose, TIMSS examines student, home, school and class factors associated with students' achievement.

Various environmental factors significantly affect students' academic achievement (Eccles \& Wigfield, 2002; Scherer \& Nilsen, 2016; Lamb \& Fullarton, 2002; Marzano, 2003; Hattie, 2009). One of these is, as defined in TIMSS 2015, school-related factors (Hooper, Mullis \& Martin, 2013): socioeconomic structures of schools, impacts of schools on academic achievement, safe and disciplined school climate, educational activities at school, and qualifications of teachers.

Also, for the first time in TIMSS 2015, a different factor was put forward that may affect the academic achievement of 4th grade students: "home context". The items in the home survey developed in this direction include factors associated with early learning experiences which are critical in childhood (Teale \& Sulzby, 1992).

The fact that the early childhood period has a significant share in the development of academic knowledge and skills in 
primary school makes the studies on this subject important. Indeed, some studies (Kyriakides, 2006; Blomeke, Suhl \& Kaiser, 2011; OECD, 2013) have reported that the interaction between parents and schools affects students' achievement. Scherer and Nilsen (2016) stated that there are a limited number of studies (Seidel \& Shavelson, 2007; Wang \& Degol, 2015) that address various school-related factors, qualifications of classroom teaching activities, and parental characteristics concerning the international academic achievement.

The present study brings together some family-based factors, early childhood experiences, and some school-related factors with the aim of investigating to what extent these factors affect students' mathematics achievement in primary school.

\subsection{The Purpose of the Research}

The overall aim of this study is to investigate the effect of school-related factors and early learning experiences on academic achievement (mathematics achievement). To this end, answers to the following questions were sought:

1. How much of the differences in students' mathematics achievements result from the differences between schools?

2. Do students' mathematics achievement scores differ regarding their early learning experiences? If there are differences, what are the early learning experiences that explain this difference?

3. How much of the variance in mathematics achievement scores is explained by the early learning experiences with significant effects?

4. Do students' mathematics achievement scores differ regarding school-related factors? If there are differences, which school-related factors explain this difference?

5. How much of the variance in mathematics achievement scores is explained by the school-related factors with significant effects?

\section{Method}

\subsection{Research Model}

Since the present study aimed to determine and compare the variables affecting the mathematics achievement scores of the 4th-grade students who participated in TIMSS 2015, it was conducted with the causal-comparative design, one of the quantitative research methods. The causal-comparative design is a research design that seeks to determine the cause or consequences of differences that already exist between or among groups of individuals. In other words, it aims to identify the causal variables that affect the consequence-related variable or the consequences of the cause without any intervention on participants and conditions (Buyukozturk, Cakmak, Akgun, Karadeniz \& Demirel, 2011, p. 226; Fraenkel, Wallen \& Hyun, 2012). Since the linear relations, as well as strong nonlinear relations, were predicted among the variables, relational screening models were not preferred in order not to fail to notice these relationships (Tabacnick \& Fidell, 2001).

\subsection{Sample}

In the first stage of the implementation of the TIMSS, schools were listed according to their demographic variables. After that, schools were determined from this list using the probability-proportional-to-size sampling method. Then, random branches were selected from the schools (LaRoche, Joncas\&Foy, 2016, p. 3.11).

TIMSS 2015 enrolled a total of 6456 Turkish fourth-grade students, the parents of these students $(n=6456)$, the teachers of these students $(n=249)$, and the principals of schools $(n=242)($ LaRoche\&Foy, 2016). As a result of the preliminary analysis, this study was carried out with data obtained from 6378 parents, 241 primary school teachers, and 241 school principals. Within the scope of the research, average mathematics achievement scores (PV1-5) of 6378 students (3148 girls and 3230 boys) were calculated.

\subsection{Data Collection Tools}

As indicators of students' mathematics achievement, the results obtained from the mathematics achievement test in TIMSS (plausible values) were used. A booklet contains an average of 10-15 mathematics questions, half of which is multiple choice and the other half is structured test-item response. The items include the following learning areas: $50 \%$ numbers, $35 \%$ geometric shapes and measurement, $15 \%$ data display. Besides, the cognitive domain distribution of items is as follows: $40 \%$ knowledge, $40 \%$ practice and 20\% reasoning (Martin, Mullis \& Foy, 2013).

"Teacher surveys" were used to obtain data on classroom teaching practices and teachers' characteristics. Of the 21 items, 11 mathematics-related items were filled in by the teachers.

Another part of school-level variables was obtained through the "school survey". The 22-item survey was filled in by the principals. All the student-level variables were obtained by the "early learning (home) survey". 
This 23-item survey was filled in by parents. The items were on the following topics: home resources that support children's reading and arithmetic skills; literacy in early childhood; children's arithmetic and science skills; parents' educational backgrounds, occupations and attitudes towards science and mathematics (Hooper et al., 2013).

\subsection{Data Collection}

The data of the study were obtained through the achievement tests and surveys applied to the 4th-grade students in TIMSS 2015 (TIMSS, 2015).

\subsection{Data Analysis}

\subsubsection{Multilevel Analysis}

The majority of the data obtained in the studies measuring the qualifications of students are hierarchical (graded) due to the sampling structure or sampling techniques (Atar, 2014). The TIMSS exhibits a hierarchical structure: students are clustered in classes, classes in schools, schools in regions and regions in countries (Hooper et al., 2013). Hox (2002) argues that the application of single-level models for the analysis of data in this structure will cause statistical and conceptual problems.

Multilevel models while working on data with hierarchical structure enables the separation of the variances within groups and between groups. Therefore, more reliable results are obtained since the effects both within and between groups can be analyzed separately. However, since single-level analysis methods require the aggregation of data at a higher level or the disaggregation of data to a lower level (Raudenbush \& Bryk, 2002; Heck and Thomas, 2009), group effect is not noticed in the disaggregation model and the individual effect not noticed in the aggregation model. Therefore, the effects of the individual or group cannot be seen (Raudenbush \& Bryk, 2002).

One of the basic assumptions of single-level analysis methods is the homoscedasticity. Multilevel models allow the calculation of within-group and between-groups variances associated with dependent variables, enabling an understanding of the effects of the levels (Raudenbush and Bryk, 2002; Hox, 2002; Heck and Thomas, 2009). Another of the basic assumptions of single-level analysis methods is the independence of observations. Osborne (2002) argues that the data obtained for different groups in a hierarchical structure tend to be more similar to each other. In this case, it is impossible to achieve completely independent observations from the students in the same unit. Multilevel models may violate the assumption of independence of observations.

Another statistical problem in the use of single-level models in the analysis of data in a hierarchical structure is that the standard errors of the regression coefficient estimates are underestimated. In this case, the severity of the estimated regression coefficients can be overestimated. In multi-level models, however, this can be eliminated by including a random effect factor $\left(u_{q j}\right)$ at each level. Thus, variability in random effects is taken into account, and standard errors can be estimated accurately (Raudenbush and Bryk, 2002).

Due to the statistical advantages mentioned in the analysis of the hierarchical data, the data of this study were analysed by the Hierarchical Linear Modelling (HLM).

\subsubsection{HLM Analysis}

Level-1 variables in the HLM are student-level variables. Level-2 variables are school-level variables. In the first stage of the analysis, the following steps were applied to the variables included in the home, teacher and school surveys and preliminary analyses were performed. After the data were arranged in line with the purpose of the study, they were included in the HLM analysis.

$>$ The Arrangement of Data: "X" refers to Level-1 variables while "W" refers to Level-2 variables. SPSS files were created for student and school-level variables. The category of multi-category variables was reduced to two.

Data Cleaning: By the purpose of the research and relevant literature, some items in the surveys were excluded from the data. Variables with index score were deleted from the data.

$>$ Correlation between Variables: Correlation between dependent variables and independent variables was examined, and student and school-level variables not correlated with the dependent variable were checked. Among the independent variables included in the study, there was none that was not correlated with the dependent variable.

Multicollinearity: The correlations of the independent variables in Level-1 were examined to see if there was multicollinearity. Multicollinearity exists whenever there is a correlation value greater than 0.90 (Tabachnick \& Fidell, 2001, 88). Among the variables predicted to be included in Level-1, those with a high (>0.90) relationship were checked. Since no highly correlated variables were found, no variables from the Level-1 file were deleted.

Missing Value Analysis: Firstly, it was checked whether the missing data in Level-1 was systematically distributed. The missing data analysis performed in the SPSS program and the significance of Little's MCAR test showed that the 
missing data was systematically distributed. If the missing data is below 5\%, the listwise method can be applied (Garson, 2008). An alternative to handling missing values for quantitative missing data of over $5 \%$ and with systematic distribution in large samples is to make estimations about the missing value (imputation) and to use these values in the actual analysis (Cokluk, Olculuoglu \& Buyukozturk, 2018, 11). The most common three methods are "the use of past information", "mean substitution", and "regression" (Tabacnick \& Fidell, 2001; Mertler \&Vannatta, 2005; Cokluk et al., 2018). In this study, the missing data without a random distribution was not deleted (the listwise method was not applied); rather, multiple imputation-MI was conducted by the SPSS regression technique. The advantage of regression over the mean substitution technique is that it is more objective than the prediction made by the researcher and contains more information than simply assigning a mean value (Tabachnick \& Fidell, 2001).

$>$ Outlier Removal: In scientific research, differentiation of any subject from the rest of the sample constitutes an outlier. Especially when working on large samples $(n>400)$, outlier removal procedure is performed to check if there is a value that is left \pm 4 points outside after values of continuous variables are converted to $Z$ points (Tabacnick \& Fidell, 2001; Mertler \& Vannatta, 2005). Once the outliers were removed from the data set, the sample of the study consisted of 6378 students, 6378 parents, 241 schools and 241 teachers.

D Exploratory Analysis: It was conducted for Level-2 variables. The t-test is one of the best indicators to determine which Level-2 variables will be included in the HLM analysis. The obtained t value shows the approximate result to be achieved when a predictor variable is added to the Level-2 equation. Therefore, if the $t$ value is greater than 1, then the corresponding variable can be included in the analysis (Raudenbush \& Bryk, 2002, p. 270). Of the 26 variables associated with mathematics achievement, the t values of 19 variables were significant. All the variables with significant $t$ value were included in the model.

Variables with insignificant $t$ value were excluded from the analysis. Finally, there were 16 student-level variables and 19 school-level variables associated with mathematics achievement.

Variables: The dependent variables were TIMSS 2015 mathematics achievement scores. The independent variables were student-level (Level-1) characteristics (home survey), and school-level (Level-2) characteristics (school and teacher surveys). Table 1 and Table 2 present descriptive statistics of the variables included in the HLM program.

Table 1. Descriptive statistics of Level-1 variables included in the HLM analysis

\begin{tabular}{cccccc}
\hline Variables & $\mathrm{N}$ & Mean & SD & Minimum & Maximum \\
\hline X12 & 6378 & 8.42 & 1.98 & 0.69 & 15.03 \\
\hline X13 & 6378 & 9.05 & 2.25 & 1.52 & 15.30 \\
\hline X14 & 6378 & 9.15 & 2.39 & 2.00 & 0 \\
\hline X15 & 6378 & 1.05 & 0.92 & 1 & 2 \\
\hline X16 & 6378 & 1.54 & 0.49 & 3.94 & 12.45 \\
\hline X17 & 6378 & 10.65 & 1.87 & 2.47 & 12.66 \\
\hline X18 & 6378 & 10.71 & 1.70 & 1 & 5 \\
\hline X19A & 6378 & 1.25 & 0.74 & 1 & 5 \\
\hline X19C & 6378 & 2.07 & 1.28 & 114.44 & 770.91 \\
\hline PV1 & 6378 & 1.93 & 1.27 & 116.41 & 766.78 \\
\hline PV2 & 6378 & 483.174 & 95.21 & 72.05 & 773.45 \\
\hline PV3 & 6378 & 482.703 & 95.58 & 84.48 & 868.08 \\
\hline PV4 & 6378 & 483.417 & 95.57 & 84.73 & 784.46 \\
\hline PV5 & 6378 & 482.573 & 96.09 & 95.87 & \\
\hline
\end{tabular}


Table 2. Descriptive statistics of Level-2 variables included in the HLM analysis

\begin{tabular}{cccccc}
\hline Variables & $\mathrm{N}$ & Mean & SD & Minimum & Maximum \\
\hline W1 & 241 & 9.07 & 2.01 & 1.11 & 16.73 \\
\hline W2 & 241 & 8.66 & 2.23 & 3.69 & 3.88 \\
\hline W3 & 241 & 2.29 & 0.80 & 1.00 & 42.00 \\
\hline W8 & 241 & 15.92 & 10.43 & 4.00 & 3.40 \\
\hline W9 & 241 & 10.31 & 1.75 & -1.62 & 15.82 \\
\hline W10 & 241 & 0.01 & 0.99 & 2.81 & 13.41 \\
\hline W12 & 241 & 9.29 & 1.97 & 3.75 & 13.57 \\
\hline W14 & 241 & 9.67 & 2.16 & 5.19 & 14.51 \\
\hline W15 & 241 & 8.95 & 2.25 & 3.00 \\
\hline W16 & 241 & 11.48 & 2.08 & 1.80 & 15.82 \\
\hline W17B & 241 & 8.77 & 1.74 & 2.81 & 4.00 \\
\hline W20C & 241 & 1.57 & 0.551 & 1.00 & 4.00 \\
\hline W20D & 241 & 9.31 & 2.03 & 1.00 & 4.00 \\
\hline W20E & 241 & 2.47 & 0.76 & 1.00 & 4.00 \\
\hline W20F & 241 & 2.88 & 0.85 & 1.00 & 3.00 \\
\hline W20G & 241 & 2.31 & 0.91 & 1.00 & 3.00 \\
\hline W20H & 241 & 1.48 & 0.74 & 1.00 & \\
\hline
\end{tabular}

"X" is encoded for Level-1 variables and "W" for Level-2 variables. Accordingly, X12 denotes learning resources at home; X13 pre-school learning activities; X14 pre-school skills; X15 level of participation in pre-school education; X16 primary school starting age; X17 parents' opinions on students' performance; X18 parents' attitudes towards science and mathematics; X19A school assignments; X19B parents' helping with assignment; and X19C parents' monitoring assignments. For these variables, parents' responses to the home survey were used. W1 denotes the importance schools attach to academic achievement; W2 a safe and disciplined school environment; and W3 socioeconomic structure of schools. For these variables, principals' responses to the school survey were used. Furthermore, W8 denotes teachers' experiences; W9 professional satisfaction; W10 self-confidence in mathematics teaching; W12 teachers' perceptions about the importance that schools attach to academic achievement (teachers); W13, perceptions of a safe and disciplined school structure (teachers); W14 problems related to school facilities and resources (teachers); W15, difficulties encountered (teachers); W16, limited education due to students' needs; W17B feedback on mathematics homework; W19 emphasis on research; 20C use of interesting material $s ; 20 \mathrm{D}$ challenging activities; 20E classroom discussions; 20F connection between new contents-previous contents; 20G deciding on problem-solving durations; and 20H expressing thoughts. For these variables, teachers' responses to the teacher survey were used.

Assumptions of HLM: Following preliminary analyses, the assumptions were first checked for HLM analysis. Using the data from the residual files created for Level-1 and Level-2, the normal distribution of residues, their homogeneity and their relations with each other were investigated. The results of the Shapiro-Wilk test for the normality of residues at both levels were significant $(p=0,000)$; Skewness and Kurtosis values within the range of +1 to $-1( \pm 1)$ indicate that the residues at both levels did not show large deviation (Cokluk, Sekercioglu \& Buyukozturk, 2012). The residues in Level-1 showed a homogeneous distribution close to normal and the variables were independent of " $r i t$ ", which is the error term at this level, and of random effects at other levels. For Level-2, the slope coefficients of the cut-off point and variables at this level showed a normal distribution. The variables were independent of " $u 0 j$ ", which is the error term at this level. Also, Level-2 errors show multiple normalities with an average of zero. Therefore, the assumptions of HLM for Level-1 and Level-2 were met.

$>$ Construction of Multivariate Data Matrix (MDM) Files: According to the results of the assumptions, MDM files were created in the HLM program, and the models related to answering the research problems were analysed through these files.

Centering the variables: In the study, centering was performed to eliminate the bias caused by the multicollinearity problem (Raudenbush \& Bryk, 2002). For the continuous variables in Level-1 and Level-2, grand-mean centering was performed; and for the categorical variables in both levels, un-centering was performed.

Random and Fixed Effects: In the two-level Hierarchical Linear Model, student-level (Level-1) variables were randomly assigned to the second model to test the significance of the error terms of the variables. The variables with significant error terms $(u O j)$ were randomly assigned to model 3 where the intersection and slope coefficients were output; the variables with insignificant error terms $(u O j)$ were fixed to the model.

Effect Size: To determine whether the interpretations as a result of the data analysis indicated significance about daily life, the effect size calculation was performed by dividing the constant coefficients obtained by the analysis 
conducted at each level to the standard deviation of the residual value at the corresponding level. An effect size of 0.41 is considered "minimum", an effect size of 1.15 is considered "medium", and an effect size of 2.70 is considered "large" (Ferguson, 2009).

With the completion of preliminary analyzes, HLM models were established. To answer the research problems, SPSS-based HLM 7.01 program developed by Raudenbush and Bryk (2002) was used, and the models were tested.

\subsubsection{HLM Models}

1) One-Way ANOVA with Random Effects: With this model, the question "How much of the differences in students' mathematics achievements result from the differences between schools?" was answered. Also, it was checked whether the HLM is suitable for the analysis of the data. In this model, there is no explanatory variable for Level-1 or Level-2 (Hox, 2002). Model equations are as follows (Raudenbush \& Bryk, 2002).

$$
\begin{aligned}
& \text { Level 1: } Y i j=\beta 0 j+r i j \\
& \text { Level 2: } \beta 0 j=\gamma 00+u 0 j
\end{aligned}
$$

Here,

"Yij" denotes the i student's mathematics achievement score at the $\mathrm{j}$ school;

" $\beta 0 j$ " denotes the average mathematics achievement score of the $\mathrm{j}$ school,

"rij" denotes the error score of the $\mathrm{i}$ student at the $\mathrm{j}$ school, i.e. the difference between the $\mathrm{i}$ student's average mathematics achievement score and the $\mathrm{j}$ school's average mathematics achievement score. It is assumed that the error score at each student level is normally distributed with " 0 " average and fixed Level-1 ( $\sigma 2)$ variance.

" $\gamma 00$ " denotes the average mathematics achievement scores of the schools;

" $u 0 j$ " denotes the error score of the $\mathrm{j}$ school, i.e. the difference between the average mathematics achievement score of the $\mathrm{j}$ school and the general average mathematics achievement score. It is assumed that the error score at each school level is normally distributed with " 0 " average and " $\tau 00$ " variance. An u0j value close to zero means that there is very little difference between schools.

2) Random Coefficients: In this model, student variables associated with mathematics scores were assigned to the Level-1 to determine which student-level variable affects mathematics achievement score. Level-2 variables are not included in this model (Raudenbush\&Bryk, 2002). Equations of the model are as follows.

$$
\begin{gathered}
\text { Level 1: } Y_{i j}=\beta_{0 j}+\beta_{1 j} X_{i j}+r_{i j} \\
\text { Level 2: } \beta_{0 j}=\gamma_{00}+u_{0 j} \\
\beta_{1 j=\gamma_{10}+u_{1 j}}
\end{gathered}
$$

Here,

" $\beta 1 j$ " denotes expected change in the average mathematics achievement scores for a one-unit change in the corresponding independent variable at the $\mathrm{j}$ school (when other predictive variables are controlled);

" $X_{i j}$ " denotes the value of the independent variable for the I student at the $\mathrm{j}$ school;

" $\beta 1 j$ " denotes expected change in the average mathematics achievement scores versus one-unit change in the corresponding independent variable at the $\mathrm{j}$ school (when other predictive variables are controlled);

" $\gamma 10$ " denotes the average school slope for the corresponding variable at the school level (the effect of the corresponding variable on the mathematics achievement score of the $j$ class);

"ulj" denotes the effect of the $\mathrm{j}$ school on the Level-1 slope.

3) Intercepts and Slopes as Outcomes Model: To Level 1 of this model established to answer the questions 4 and 5 , student-level variables, and to Level 2, school-level variables were assigned. Then, the HLM analysis was performed. School-level variables associated with mathematics achievement scores were determined. Also, the relationship between school-level variables and student-level variables could be observed. Equations of the model established in this direction are as follows (Raudenbush\&Bryk, 2002):

$$
\begin{gathered}
\text { Level 1: } Y_{i j}=\beta_{0 j}+\beta_{i j} X_{i j}+r_{i j} \\
\text { Level 2: } \beta 0 j=\gamma 00+\gamma 01\left(W_{j}\right)+u 0 j \\
\quad \beta 1 j=\gamma 01+\gamma 11\left(W_{j}\right)+u 1 j
\end{gathered}
$$

Here, 
" $\gamma 00$ " denotes Level-1 intercept in the case any school has a value of 0 in the corresponding independent value (W=0);

" $\gamma 01$ " denotes the estimated effect of a unit change in the corresponding school-level variable on average mathematics achievement scores when other predictive variables in the model are controlled;

" $W_{j}$ " denotes the corresponding independent value at school-level;

" $\gamma 10$ " denotes the estimated Level-1 slope for a group with $\mathrm{W}=0$;

" $u 1$ ” denotes the effect of the $\mathrm{j}$ school in Level-1 slope when $\mathrm{W} j$ is kept constant

\section{Results}

\subsubsection{Research Problems}

Table 3a. and Table 3b. present the results of the analysis of the One-Way ANOVA with Random Effects conducted to determine whether there is a difference between the mathematics achievement scores of the schools in TIMSS 2015.

Table 3a. One-Way ANOVA Fixed Effects Model Analysis Results

\begin{tabular}{cccccc}
\hline Fixed Effects & Coefficients & $\begin{array}{c}\text { Standard Error } \\
(\text { SE) }\end{array}$ & $T$ & $\begin{array}{c}\text { Approximate } \\
\text { s.d. }\end{array}$ & $p$ \\
\hline Cut-off Point, $\gamma 00$ & $481.49^{*}$ & 3.98 & 120.97 & 240 & 0.000 \\
\hline
\end{tabular}

${ }^{*} p<0.05$

According to Table 3a., the average mathematics achievement score can be estimated as 481.49 with a standard error of 3.98. When the confidence interval is calculated for the estimated overall averages $[\% 95 \mathrm{CI}(\gamma 00)=\gamma 00 \pm(1.96)(\mathrm{SH})]$, the real value of the average mathematics achievement scores is expected to be between 483.45 and 479.53 . Furthermore, the reliability coefficient of the overall average of mathematics achievement scores was 0.927 . According to these results, fixed parameters were significant $(p<0.05)$. Mathematics achievement varies significantly between schools. In this respect, the data has a nested structure, and therefore it should be analysed with multilevel models.

Table 3b. One-Way ANOVA Random Effects Model Analysis Results

\begin{tabular}{cccccc}
\hline Random Effects & Standard Deviation & Variance Component & s.d. & $\chi 2$ \\
\cline { 2 - 6 } & Level $-2,\left(\boldsymbol{u}_{\boldsymbol{0}}\right)$ & $59.56^{*}$ & 3547.72 & 240 & 4435.79 \\
\cline { 2 - 6 } & Level $-1,\left(\boldsymbol{r}_{\boldsymbol{i} \boldsymbol{j}}\right)$ & 74.31 & 5522.79 & & \\
\cline { 2 - 6 }
\end{tabular}

In Table 3b, intra-school variability $(\sigma 2)$ on average mathematics achievement score was estimated as 5522.79 while the inter-school variability $(\tau 00)$ was estimated as $3547.72(\chi 2=4435.79$, s.d. $=240)$. The extent to which the variability between mathematics achievement scores is explained by the levels is calculated using the inter-class correlation (ICC) (Raudenbush \& Bryk, 2002).

$$
\begin{aligned}
& \rho=\sigma 2 /(\tau 00+\sigma 2): 5522.79 /(3547.72+5522.79)=0.60 \\
& \rho=\tau 00 /(\tau 00+\sigma 2): 3547.72 /(3547.72+5522.79)=0.40
\end{aligned}
$$

Accordingly, $40 \%$ of the total variability in the mathematics achievement scores is due to the differences between schools, and $60 \%$ is due to the differences between students.

\subsection{Research Problems}

According to the results of the analyzes of the Random Coefficient-Regression Model established to find answers to the 2nd and 3rd problems, six student-level variables [parents' monitoring children's assignments (X19A), parents' helping children with their assignments (X19B), learning resources at home (X12), pre-school learning activities (X13), pre-school skills (X14), parents' attitudes towards science and mathematics (X18)] have significant effects on mathematics achievement scores $(p<0.05)$ while four variables [parents' control of children's assignments (X19C), parents' views on school performance (X17), level of participation in pre-school education (X15), primary school starting age (X16)]] do not have significant effects $(p>0.05)$.

The variables with insignificant effects on mathematics achievement scores [X19C ( $\gamma 80=4.98, S H=2.10, p>0.05), \mathrm{X} 17$ $(\gamma 80=4.98, S H=2.10, p>0.05), \mathrm{X} 15 \quad(\gamma 80=0.43, S H=1.18, p>0.05)$, ve X16 $(\gamma 80=2.21 S H=2.24, p>0.05)]$ were excluded from the analysis and the Final Random Coefficient Regression Model was established. The results of the fixed effects and variance components of the final model obtained by the final analysis are given below. 
Table 4a. Estimation of Fixed Effects of Random Coefficient Regression Model

\begin{tabular}{|c|c|c|c|c|c|c|}
\hline Fixed Effects & Coefficients & Standar Error & $t$ & Approximate sd & $p$ & Effect Size \\
\hline $\begin{array}{c}\text { Cut-off point } 1, \beta_{0} \\
\text { Cut-off point } 2, \gamma 00\end{array}$ & 481.42 & 3.99 & 120.64 & 240 & 0.000 & ----- \\
\hline $\begin{array}{c}\text { X19A Slope, } \beta 1 \\
\text { Cut-off point } 2, \gamma 10\end{array}$ & -3.96 & 1.86 & -2.12 & 130 & 0.035 & -0.05 \\
\hline $\begin{array}{c}\text { X19B Slope } \beta_{2} \\
\text { Cut-off point } 2, \gamma 20\end{array}$ & 2.91 & 0.96 & 3.03 & 57 & 0.004 & 0.03 \\
\hline $\begin{array}{c}\text { X12 Slope, } \beta_{4} \\
\text { Cut-off point } 2, \gamma 40\end{array}$ & 11.78 & 0.76 & 15.37 & 240 & 0.000 & 0.15 \\
\hline $\begin{array}{c}\text { X13, } \beta_{5} \\
\text { Cut-off point } 2, \gamma 50\end{array}$ & 4.79 & 0.76 & 15.37 & 240 & 0.000 & 0.06 \\
\hline $\begin{array}{c}\text { X14 Slope, } \beta 6 \\
\text { Cut-off point } 2 \gamma 60 \\
\end{array}$ & 4.31 & 0.54 & 7.84 & 240 & 0.000 & 0.05 \\
\hline $\begin{array}{c}\text { X18 Slope, } \beta_{8} \\
\text { Cut-off point } 2, \gamma 80\end{array}$ & 1.03 & 0.65 & 1.58 & 240 & 0.114 & ----- \\
\hline
\end{tabular}

According to Table 4a., the average mathematics achievement scores of the schools as a result of the variables in the analysis is 481.42. This value reflects a student's score if the student's other variables in the model are equal to the average value of the group.

"Learning resources at home (X12)" variable has the highest effect on the average mathematics achievement of schools. $\left(\beta_{4}\right)$ was estimated to be approximately 11.78 with a standard error of about 0.76 . Since the $p$-value of this coefficient was statistically significant $(p<0.05$, sd. $=240)$, when the other variables in the model are controlled, a one-unit increase in learning resources at home may result in an 11.79 unit increase in the students' mathematics achievement scores. Furthermore, the average mathematics achievement score of students with a lot of learning resources at home is 11.79 units more than the students with less learning resources at home. When a $95 \%$ confidence interval for $\left(\beta_{4}\right)$ is generated, its actual value is expected to be in the range of 13.75 to 9.83 . Considering its sie (0.15), the effect of this variable is too small to be felt in daily life.

The variable "parents' helping the children with their assignments (X19B)" has the lowest effect on the average mathematics achievement of schools $\gamma 20=2.91, S H=0.96, p<0.05)$. Finally, the variable "parents' attitudes towards Science and Mathematics (X18)" does not significantly affect students' academic achievements $(\gamma 60=1.03, S H=0.65$, $p>0.05)$.

Table $4 \mathrm{~b}$ presents the estimation of the variance components of the Final Random Coefficient-Regression Model to determine how students' mathematics achievement scores differ between schools according to their early learning experiences.

Table 4b. Estimation of the Variance Components of the Final Random Coefficient Regression Model

\begin{tabular}{cccccc}
\hline Random Effect & $\begin{array}{c}\text { Standard } \\
\text { Deviation }\end{array}$ & $\begin{array}{c}\text { Variance } \\
\text { Component }\end{array}$ & s.d. & $\chi^{2}$ & $p$ \\
\hline Level-2 Error Term, $u_{0 i}$ & 59.912 & 3589.55 & 209 & 5120.00955 & 0.000 \\
\hline X19A Slope, $u 1$ & 11.202 & 125.49 & 209 & 125.49005 & 0.034 \\
\hline X19B Slope, $u 2$ & 3.635 & 13.21 & 209 & 204.46677 & $>.500$ \\
\hline X12 Slope, $u 3$ & 6.140 & 37.71 & 209 & 265.42784 & 0.005 \\
\hline X13 Slope, $u 4$ & 3.175 & 10.08 & 209 & 218.24732 & 0.316 \\
\hline X14 Slope, $u 5$ & 3.286 & 10.80 & 209 & 240.56226 & 0.066 \\
\hline X18 Slope, $u 6$ & 4.697 & 22.06 & 209 & 247.60361 & 0.035 \\
\hline Level-1 Error Term, $r i j$ & 67.968 & 4619.66 & & & \\
\hline
\end{tabular}

According to Table 4b, random effects of $u 1, u 3, u 6$ coefficients are significant $(p<0.05)$. The residual variance at student level (4619.66) is smaller than the variance (5522.79) obtained in the ANOVA model. This indicates that the difference between the students in mathematics achievement scores decreases by the addition of early learning experiences.

In line with the "[(5522.79-4619.70)/5522.79]=0.16" value obtained by the " [ $\sigma 2($ ANOVA)- $\sigma 2$ (Final Random Coefficient Model)]/ $\sigma 2($ ANOVA)] " operation to explain how the inclusion of determined student-level variables in the model reduces the random error variance at the student level, $16 \%$ of the differences between students' mathematics achievement scores $(60 \%)$ is explained by parents' monitoring their children's assignments, parents' helping with their children's assignments, learning resources at home, pre-school learning activities, and pre-school skills. The remaining $84 \%$ of the variance can be explained by other student-level variables not included in this model. 


\subsection{Findings on the 4th and 5th Research Problems}

To answer the 4th and 5th questions, HLM analysis was established in which the intersection and slope coefficients were the dependent variables. According to the analysis of the model, the variables included in the model [the importance the school attaches to academic achievement (W1) $(\gamma 01=7.57, S H=1.96, p<0.05)$, a safe and disciplined school environment (W2) $(\gamma 02=3.60, S H=1.46, \mathrm{p}<0.05)$, socioeconomic structure of the school (W3) $(\gamma 03=-10.54$, $S H=4.51, p<0.05)$, teachers' experiences (W8) $(\gamma 04=1.47, S H=0.306, p<0.05)$, and teachers' perceptions of the importance that the school attaches to academic achievement (W12) $(\gamma 14=5.73, S H=2.33, p<0.05)$ ] significantly affect students' mathematics achievement.

The variables with insignificant effects were excluded from the model, and the analyses were repeated. The final model was established only with the variables with significant effects. Table 5a presents the results of the final analysis.

Table 5a. Estimation of Fixed Effects of the Final Model where the Intersect and Slope Coefficients were Output

\begin{tabular}{|c|c|c|c|c|c|}
\hline Fixed Effects & Coefficients & $\begin{array}{l}\text { Standard } \\
\text { Error }\end{array}$ & $\mathrm{t}$ & $p$ & Effect Size \\
\hline $\begin{array}{c}\text { Average Mathematics } \\
\text { Achievement, } \beta 0 \\
\text { Fixed } 00\end{array}$ & 481.322 & 3.00 & 160.113 & 0.000 & ----- \\
\hline $\mathrm{W} 1, \gamma 01$ & 8.530 & 1.88 & 4.528 & 0.000 & 0.14 \\
\hline $\mathrm{W} 2, \gamma 02$ & 3.482 & 1.39 & 2.504 & 0.013 & 0.05 \\
\hline W3, $\gamma 03$ & -10.276 & 4.37 & -2.348 & 0.020 & 0.17 \\
\hline W8, $\gamma 04$ & 1.518 & 0.29 & 5.517 & 0.000 & 0.02 \\
\hline $\mathrm{W} 12, \gamma 014$ & 5.829 & 1.72 & 3.378 & 0.001 & 0.09 \\
\hline $\begin{array}{l}\text { X19A Model for Slope, } \beta 1 \\
\text { Fixed, } \gamma 10\end{array}$ & -4.09 & 1.88 & -2.174 & 0.031 & ---- \\
\hline $\begin{array}{c}\text { X19B Model for Slope, } \beta 2 \\
\text { Fixed, } \gamma 20\end{array}$ & 2.955 & 0.94 & 3.126 & 0.000 & ----- \\
\hline $\begin{array}{c}\text { X12 Model for Slope, } \beta 4 \\
\text { Fixed, } \gamma 40\end{array}$ & 11.865 & 0.76 & 15.514 & 0.000 & ----- \\
\hline $\begin{array}{c}\text { X13 Model for Slope, } \beta 5 \\
\text { Fixed, } \gamma 50\end{array}$ & 4.830 & 0.68 & 7.047 & 0.000 & ----- \\
\hline $\begin{array}{c}\text { X14 Model for Slope, } \beta 6 \\
\text { Fixed, } \gamma 60\end{array}$ & 4.162 & 0.50 & 8.316 & 0.000 & ---- \\
\hline $\begin{array}{l}\text { X18 Model for Slope, } \beta 8 \\
\text { Fixed, } \gamma 80\end{array}$ & 0.914 & 0.66 & 1.369 & 0.172 & ---- \\
\hline
\end{tabular}

The socioeconomic structure of the school (W3) has the highest impact on the average mathematics achievement of schools. However, this effect is negative. After controlling other variables in the model, the effect of the variable on the average mathematics achievement of schools was estimated as -10.276 ; the standard error of the estimation is 4.37 . A one-unit increase in schools where students with poor economic background are enrolled will cause a decrease of 11 points in mathematics achievement scores. The effect $(0.17)$ of the variable with a statistically significant $(p<0.05)$ effect on mathematics achievement is felt at a moderate level in daily life.

The variable "teachers' experiences" (W8) has the lowest impact on the average mathematics achievement of schools. After controlling other variables in the model, the effect of W8 on the average mathematics achievement of schools was estimated to be 1.51. A one-unit increase in teachers' experience variable will produce an increase of approximately 1.50 points in students' mathematics achievement scores. The effect of the variable with a statistically significant effect $(p<0.05)$ on mathematics achievement is felt at a moderate level in daily life.

Also, considering the coefficients of the variables associated with early learning experiences in this final model, there is no significant change in the gamma $(\beta)$ coefficients compared to the previous models $((\beta 1=-4.09, \beta 2=2.95, \beta 3=11.86$, $\beta 4=4.83, \beta 5=4.16$ and $\beta 6=0.91)$ and their significant effects are continuing. Table $5 \mathrm{~b}$ presents the estimation of the variance components of the final model, where the intersection and slope coefficients are the dependent variables.

Table 5b. Estimation of the variance components of the Final Model, where the intersection and slope coefficients are the dependent variables

\begin{tabular}{cccccc}
\hline Random Effect & $\begin{array}{c}\text { Standard } \\
\text { deviation }\end{array}$ & $\begin{array}{c}\text { Variance } \\
\text { Component }\end{array}$ & s.d. & $\chi^{2}$ & $p$ \\
\hline Level-2 Error Term, $u_{0 i}$ & 43.93 & 1930.19 & 208 & 2650.240 & 0.000 \\
\hline $\mathrm{X} 19 \mathrm{~A}, u_{\boldsymbol{l}}$ & 11.81 & 139.49 & 213 & 288.601 & 0.001 \\
\hline $\mathrm{X} 12, u 3$ & 6.11 & 37.36 & 213 & 310.163 & 0.000 \\
\hline $\mathrm{X} 18, u 6$ & 5.03 & 25.32 & 213 & 289.095 & 0.001 \\
\hline Level-1 Error Term, $r i j$ & 68.47 & 4689.20 & & & \\
\hline
\end{tabular}


When the variance components of the model were examined, the variance of the average mathematical achievement of schools (residual variance) was determined as 1930.19 after controlling X19A, X12, and X18 at the school level. For average mathematics achievements, the variance ratio index explained by " $\tau_{000}$ (Model 2)- $\tau 00$ (Model 3) / $\tau 00$ (Model 2)]" was calculated between the estimated variance values of Random Coefficient Regression Model (Model 2) and the Model where the Intersect and Slope Coefficients are output

This value (46\%) shows that about $46 \%$ of the differences between schools in mathematics achievement (40\%) are explained by school-level variables (W1, W2, W3, W8, and W12) with significant effects. The remaining 54\% of the variance can be explained by other school-level variables not included in this model.

Also, $40 \%$ of the difference between mathematics achievement scores can be explained by differences between schools according to the results of One-Way ANOVA Random Effects. Accordingly, 18\% of the students' mathematics achievement $(\% 40 * \% 46)$ can be explained by the school-level variables.

\section{Discussion and Conclusion}

Considering the objectives and theoretical approach of the study, ten variables from the parent survey and 19 variables from the teacher and school survey were included in the HLM analysis.

Firstly, the extent to which the levels explain the differences in mathematics achievement scores was investigated. Recent meta-analysis studies (Sirin, 2005; Hattie, 2009) indicate that the predictions of differences in students' achievement are divided into two. Some studies (Yilmaz \& Aztekin, 2012; Mohammadpour \& Abdul Ghafar, 2014; Ipekcioglu Onal, 2015) reported that school-level variables explain most of the differences in students' achievement. There are also some studies (Ryoo, 2001; Akyuz\&Berberoglu, 2010; Aydin, 2015) suggesting that school-level variables explain a part of the differences in students' achievement. In this study, student-level variables explain a large part of the variance in mathematics achievement scores. It can, therefore, be argued that various student-level factors in Turkey affect academic achievement more.

The second part of the study examines the effects of early learning experiences on mathematics achievement scores. A meta-analysis of the studies on student-level factors associated with students' achievement (Marzano, 2003; Hattie, 2009) indicates that student-level factors have a high impact on the determinants of academic achievement. According to Hox (1995), student-related features forming the basis of measurement activities in education may be students' attitudes, readiness, interests, etc. in a certain subject. The factors associated with students' parents, school and class affect these features. Nilsen, Gustafsson, and Blomeke (2016) state that students' past experiences and characteristics have a significant impact on the student outputs. Schmidt and Cogan (1996) argue that parents' educational backgrounds, learning activities at home, and educational resources also affect students' achievement. Dewald, Meijer, Oort, Kerkhof, and Bogels (2010) stated that educational conditions at home and socio-economic levels of parents affect students' achievement. Bradley and Corwyn (2002) state that students who are advantageous regarding learning resources at home are more successful at school than others. Furthermore, a positive parent-child relationship has a positive effect on academic achievement (Dahl\&Lochner, 2005).

Given these studies, it is possible to bring together the variables that affect students' achievement under the heading of early learning experiences (Epstein, 1992; Huira, 1996; Arnold, Zeljo, Doctoroff \& Ortiz, 2008). Therefore, learning resources at home, pre-school skills, early learning activities, and healthy parent-child relationships about the child's assignments are examined in studies on early learning experiences (Epstein, 1992). As a result of this study, the variables with significant effects on academic skills are consistent with the literature on the components of early learning experiences.

To determine the extent to which parents support the learning process, Akyuz (2006) examined the relationship of parental involvement with academic achievement. Uninvolved parenting, evaluated as a limitation in the teaching process, has a negative effect on academic achievement. However, according to the results of this research, parents' monitoring their children's assignments has significant negative effects while parents' helping with students' assignments has positive effects on achievement. Therefore, the fact that students' achievement increases as their parents help with their assignments is consistent with the findings of Akyuz (2006). However, another finding of this research is that the academic achievement of students whose parents monitor their assignments is lower than that of those whose parents do not. Students may be displeased with parental monitoring, and their achievements may be negatively affected by this. If the parents who do not monitor their children's assignments are considered as "neglectful", then the findings of the present study are not consistent with those of Akyuz (2006).

Besides, the results of the study indicate that the attitudes of parents toward the courses have no significant effect on academic achievement. Lyons (2006) states that students' attitudes towards science and mathematics and hence their performance in these courses are influenced by their parents' perspectives on these courses. Parents' positive attitudes 
towards science and mathematics increase students' science and mathematics achievement. Ipekcioglu Onal (2015) found insignificant relationships between parental involvement and students' achievement. The results of this study are partly consistent with previous studies because parents' attitudes towards science and mathematics have insignificant effects on students' achievement.

In the final part of the study, the effects of school-level factors on mathematics achievement scores were examined. The importance that the school attaches to academic achievement (responses of principals), teachers' perceptions about it, and a safe and disciplined school environment have significant effects on academic achievement. The meta-analysis study by Hattie (2012) reported the significant effects of school-related factors on academic achievement. In their study on the determinants of student outputs, Nilsen et al. (2016) stated that the importance attached by schools to academic achievement, perceptions of teachers about it, and a safe and disciplined school environment affect students' achievement.

Some studies (Buluc, 2014; Olculuoglu \& Cetin, 2016) stated that the importance of the safe and disciplined school environment and the importance that schools attach to academic achievement significantly affect academic achievement. Furthermore, some studies (Freiberg\&Stein, 1999; Stanco, 2012) reported a low academic achievement in schools where incidents of property damage and theft, and threats and verbal abuse among students frequently occur. Nilsen and Gustafsson (2014) argued that a safe and disciplined school environment would also enhance the school's emphasis on academic achievement and make it easier to focus on learning. Therefore, the results of the present study are consistent with those of previous studies.

The socioeconomic structure of the school is also one of the variables with significant effects. Agirdag, Van Houtte and Van Avermaet (2012) stated that students from poor socio-economic backgrounds are more likely to develop apathy towards school, arguing that academic achievement is negatively affected by this situation. One of the variables with significant effects is the experience of teachers. Akyuz (2006) and Atar (2014) stated that teachers' experiences do not have significant effects on students' achievement. However, there are also studies reporting that teachers' experiences have significant effects on students' achievement (Rice, 2003; Leigh, 2010; Harris \& Sass, 2011).

According to the results of this research, students' academic performance varies from school to school in Turkey. The most important reason for this variance is socioeconomic factors. Similarly, the academic performance of students varies according to the educational conditions, especially in the early childhood period. International studies such as TIMSS allow countries to compare the academic performance of students at a global level. Another contribution of TIMSS to countries is that it provides policymakers with information on how much of the differences in the performance levels of participating students result from regional differences and how much from socioeconomic differences. This information is essential regarding equal opportunities in education. Therefore, the results of this research can provide some ideas to the relevant institutions and organizations in Turkey on educational practices. The findings of this study support the need for preschool education and the steps to be taken in the education of families in Turkey. Similarly, it can also be inferred from the findings of the research that students' motivation and achievement will increase as a result of efforts by principals and teachers on academic achievement. In this regard, to ensure and maintain a positive climate in schools, all the officials, principals and teachers in particular need to undertake fundamental responsibilities and take beneficial steps. The findings of the study are also of particular concern to parents. Important effects of parent-child communication on students' academic achievements highlight the importance of school-family cooperation and parent-centered activities both in pre-school and primary school periods.

\section{References}

Agirdag, O., Van Houtte, M., \& Van Avermaet, P. (2002). Why does the ethnic and socio-economic composition of schools influence math achievement? The role of sense of futulity and futulity culture. Europian Sociological Review, 28(3), 366-378. https://doi.org/10.1093/esr/jcq070

Akyuz, G. (2006). Türkiye ve Avrupa Birligi ülkelerinde ögretmen ve sınıf niteliklerinin matematik basarısına etkisinin incelenmesi. Ilkögretim Online, 5(2), 75-86.

Akyuz, G., \& Berberoglu, G. (2010). Teacher and classroom chracteristics and their relations to mathematics achievement of the students in the tımss. New Horizons in Education, 58(1), 77-95.

Arnold, D. H., Zeljo, A., Doctoroff, G. L., \& Ortiz, C. (2008). Parent involvement in preschool: predictors and the relation of involvement to preliteracy development. School Psychology Review, 37(1), 74-90.

Atar, H. Y. (2014). Multilevel effects of teacher charecteristics on TIMSS 2011 science achievement (Large-scale assessment special issue). Education and Science, 39(172), 121-137.

Aydin, M. (2015). Ogrenci ve okul kaynakl faktorlerin TIMSS matematik basarısina etkisi. Doktora Tezi, Necmettin Erbakan Universitesi Egitim Bilimleri Enstitüsü, Konya. 
Blomeke, S., Suhl, U., \& Kaiser, G. (2011). Teacher education effectiveness: Quality and equity of future primary teachers' mathematics and mathematics pedagogical content knowledge. Journal of Teacher Education, 62, 154171. https://doi.org/10.1177/0022487110386798

Bradley, R. H., \& Corwyn, R. F. (2002). Socieconomic status and child development. Annual Review of Psychlogy, 53, 371-399. https://doi.org/10.1146/annurev.psych.53.100901.135233

Buluc, B. (2014). TIMSS 2011 sonucları cercevesinde, okul iklimi degiskenine gore ogrencilerin matematik basar1 puanlarının analizi. Gazi Universitesi Endustriyel Sanatlar Egitim Fakultesi Dergisi, 33, 105-121.

Buyukozturk, S, Kılıc, C. E., Akgun, O. E., Karadeniz, S., \& Demirel, F. (2011). Bilimsel arastırma yontemleri. Ankara: Pegem Akademi.

Cokluk, O., Sekercioglu, G., \& Buyukozturk, S. (2018). Sosyal bilimler için cok degiskenli istatistik SPSS ve LISREL uygulamaları. Ankara: Pegem.

Dahl, G. B., \& Lochner, L. (2005). The impact of family income on child achievement. (Working Paper No. 11279). Cambridge, MA: The Natioal Bureau of Economic Research. https://doi.org/10.3386/w11279

Dewald, J. F., Meijer, A. M., Oort, F. J., Kerkhof, G. A., \& Bögels, S. M. (2010). The influence of sleep quality, sleep duration and sleepiness on school performance in children and adolescents: A meta-analytic review. Sleep Medicine Reviews, 14(3), 179-189. https://doi.org/10.1016/j.smrv.2009.10.004

Eccles, J. S., \& Wigfield, A. (2002). Motivational beliefs, values, and goals. Annual Review of Psychology, 53(1), 109132. https://doi.org/10.1146/annurev.psych.53.100901.135153

Epstein, J. L. (1992). School and family partnerships. Center on families, communities, schools \& children's learning. https://archive.org/stream/ERIC_ED343715/ERIC_ED343715_djvu.txt.

Fraenkel, J. R., Wallen, N. E., \& Hyun, H. H. (2012). How to design and evaluate research in education. New York, NY: McGraw- Hill.

Garson, D. (2008). Data imputation for missing values. (Reprinted from http://faculty.chass.ncsu.edu/garson/PA765/missing.htm

Harris, D. N., \& Sass, T. R. (2011). Teacher training, teacher quality and student achievement. Journal of Public Economics, 95(7-8), 798-812. https://doi.org/10.1016/j.jpubeco.2010.11.009

Hattie, J. (2009). Visible learning: A synthesis of over 800 meta-alyses relating to achievement. New York, NY: Routledge.

Hattie, J. (2009). Visible learning: A synthesis of over 800 meta-alyses relating to achievement. Newyork: Routledge.

Hattie, J. (2012). Visible learning for teachers: maximizing impact on learning. New York, NY: Taylor \& Francis. https://doi.org/10.4324/9780203181522

Heck, R. H., \&Thomas, S. L. (2009). An introduction to multievel modeling techniques. New York, Routledge.

Hooper, M., Mullis, I. V. S., \& Martin, O. M. (2013). TIMSS 2015 Context questionnaire framework. In I. V. S. Mullis \&, M. O. Martin (Eds.), TIMSS 2015 assessment frameworks (pp. 61-80). United States Boston College: TIMSS and PIRLS International Study Center

Hox, J. J. (2002). Applied multilevel alaysis. Mahwah, NJ: Erlbaum. https://doi.org/10.4324/9781410604118

Huira, N. (1996). Individual communication between parents and teachers. International Journal of Early Childhood, 28(1), 8-11. https://doi.org/10.1007/BF03174512

IEA Home Center (2017). About Us. Retrieved from http://www.iea.nl/about-us

Ipekcioglu, O. S. (2015). TIMSS 2011 cross country comparisons: relationship between student-and teacher-level factors and $8^{\text {th }}$ grade students' achievement and atttude toward science (Unpublished doctoral dissertation) Middle East Technical University, Ankara, Turkey.

Kyriakides, L. (2006). Using international comparative studies to develop the theoretical framework of educational effectiveness research: A secondary analysis of TIMSS 1999 data. Educational Research and Evaluation, 12(6), 513-534. https://doi.org/10.1080/13803610600873986

Lamb, S., \& Fullarton, S. (2001). Classroom and school factors affecting mathematics achievement: A comparative study of Australia and the United States using TIMSS. Australian Journal of Education, 46(2), 154-171. https://doi.org/10.1177/000494410204600205

LaRoche, S., \& Foy, P. (2016). Sample implementation in TIMSS 2015. In M. O. Martin, I. V. S. Mullis, \& M. Hooper 
(Eds.), methods and procedures in TIMSS 2015 (pp. 5.1-5.170). (Reprinted from http://timssandpirls.bc.edu/publications/timss/2015 methods/chapter-5.html)

LaRoche, S., Joncas, M., \& Foy, P. (2016). Sample design in TIMSS 2015. In M. O. Martin, I. V. S. Mullis, \& M. Hooper (Eds.), Methods and Precedures in TIMSS 2015 (pp. 3.1-3.37). (Reprinted from http://timssandpirls.bc.edu/publications/timss/2015 methods/chapter-3.html)

Leigh, A. K. (2010). Estimating teacher effectivenes from two-year changes in students'test scores. Economics of Education Review, 29(3), 480-488. https://doi.org/10.1016/j.econedurev.2009.10.010

Lyons, T. (2006). Different countries, same science classes: Students' experience of school science classes in their own words. International Journal of Science Education, 28, 591-613. https://doi.org/10.1080/09500690500339621

Martin, M. O., Mullis, I. V. S., \& Foy, P. (2013). TIMSS 2015 Assessment Design. In In I. V. S. Mullis, \& M. O. Martin (Eds.), TIMSS 2015 assessment frameworks (85-98). Chesnut Hill, MA: TIMSS \& PIRLS International Study Center, Boston College.

Marzano, R. J. (2003). What works in school: translating research into action (1st ed.). Alexandria, Va: Association for Supervision \& Curriculum Development.

Mohammadpour, E., \& Abdul, G. M. N. (2014). Mathematics achievement as a function of within-and-between school differences. Scandinavian Journal of Educational Research, 58(2), 189-221. https://doi.org/10.1080/00313831.2012.725097

Nilsen, T., \& Gustafsson, J. E. (2014). School emphasis on academic success: exploring changes in science performance in Norway between 2007 and 2011 employing two-level SEM. Educational Research and Evaluation: An International Journal on Theory and Practice, 20(4), 308-327. https://doi.org/10.1080/13803611.2014.941371

Nilsen, T., Gustafsson, J. E., \& Blömöke, S. (2016). Conceptual framework and methodology of the report. In T. Nilsen \& J. E. Gustafsson (Eds.), Teacher quality, instructional quality and student outcomes, relationships across countries, cohorts and time (pp. 1-21). Switzerland: IEA Publishing. https://doi.org/10.1007/978-3-319-41252-8_1

OECD (2013). Education policy Outlook: Turkey. Retrieved from http://www.oecd.org/edu/EDUCATION\%20POLICY\%20OUTLOOK\%20TURKEY_EN.pdf

Olculuoglu, R., \& Cetin, S. (2016). TIMSS 2011 8. sinıf ogrencilerinin matematik basarısını etkileyen degiskenlerin bolgelere gore incelenmesi. Egitimde ve Psikolojide Olcme ve Degerlendirme Dergisi, 7(1), 202-220.

Osborne, J. W. (2002). Notes on the use of data transformations. Practical Assessment, Research, and Evaluation., 8

Raudenbush, S. V., \& Bryk, A. S. (2002). Hierarchical linear models: applications and data analysis methods. London: Sage.

Reddy, V. (2005). Cross-national achievement studies: learning from South Africa's participation in the Trends in International Mathematics and Science Study (TIMSS). Compare: A Journal of Comparative and International Education, 35(1), 63-77. https://doi.org/10.1080/03057920500033571

Rice, J. K. (2003). Teacher quality: Understanding the effectiveness of teacher attributes. Washington, D.C.:Economic Policy Institute.

Ryoo, H. (2001). Multilevel influences on student achievement: An international comparative study (Doctoral Dissertation). Avaible from ProoQuest Dissertations and Theses database.

Scherer, R., \& Nilsen, T. (2016). The relations among school climate, instructional quality, and achievement motivation in mathematics. In T. Nilsen \& J. E. Gustafsson (Eds.), Teacher quality, instructional quality and student outcomes, relationships across countries, cohorts and time (pp. 51-81). Switzerland: IEA Publishing. https://doi.org/10.1007/978-3-319-41252-8_3

Schmidt, W. H., \& Cogan, L. S. (1996). Development of the TIMSS context questionnaires. In M. O. Martin, and D. L. Kelly (Eds.), Technical report volume 1: Design and development (pp. 5.1- 5.13). Chesnut Hill, MA: TIMSS International Study Center, Boston College.

Seidel, T., \& Shavelson, R. J. (2007). Teaching effectiveness research in the last decade: Role of theory and research design in disentangling meta-analysis results. Review of Educational Research, 77, 454-499. https://doi.org/10.3102/0034654307310317

Sirin, S. R. (2005). Socioeconomic status and academic achievement: A meta- analytic review of research. Review of Educational Research, 75(3), 417-453. https://doi.org/10.3102/00346543075003417

Stanco, G. (2012). Using TIMSS 2007 data to examine STEM school effectiveness in an international context (Doctoral 
Dissertation, Lynch School of Education, Boston College, England). Retrieved from https://dlib.bc.edu/islandora/object/bc-ir:101162

Tabachnick, B. G., \& Fidell, L. S. (2001). Using multivariate statistics. Boston: Ally and Bacon.

Teale, W. H., \& Sulzby, E. (1992). Emergent literacy writing and reading. Norwood, New Jersey: Ablex Publishing Corporation.

TIMSS (2015). International database. Retrieved September 10, 2018, from https://timssandpirls.bc.edu/timss2015/international-database/

Wang, M. T., \& Degol, J. L. (2015). School climate: A review of the construct, measurement, and impact on student outcomes. Educational Psychology Review, 1-38. Retrieved from https://link.springer.com/article/10.1007\%2Fs10648-015-9319-1

Yılmaz, H. B., \& Aztekin, S. (2012, Haziran). Turkiye'deki 15 yaş grubu ogrencilerin matematik okuryazarllgl basarların etkileyen bazı faktorlerin okul ve ogrenci duzeyine gore incelenmesi. X. Ulusal Fen Bilimleri ve Matematik Egitimi Kongresi, Nigde, Turkiye.

\section{Copyrights}

Copyright for this article is retained by the author(s), with first publication rights granted to the journal.

This is an open-access article distributed under the terms and conditions of the Creative Commons Attribution license which permits unrestricted use, distribution, and reproduction in any medium, provided the original work is properly cited. 